\title{
Zinc concentrations in leucocytes of patients receiving antiepileptic drugs
}

\author{
W C YUEN, * R WHITEOAK, $†$ R P H THOMPSON $\dagger$ \\ From the *Department of Neurology, and †Gastrointestinal Laboratory, The Rayne Institute, St Thomas's \\ Hospital, London
}

SUMMARY To determine whether some of the side effects of antiepileptic drugs could be due to zinc depletion within tissues, zinc concentrations in the polymorphonuclear leucocytes in 26 epileptic patients receiving valproate or carbamazepine and 14 controls were assessed. There was no difference in zinc concentration in leucocytes among the three groups and no evidence of zinc depletion. Valproate and carbamazepine may affect the intracellular distribution of zinc.

It has been suggested that the side effects of antiepileptic drugs may in part be due to a dietary or pharmacological deficiency of zinc, or even to a redistribution of zinc within tissues as antiepileptic drugs such as phenytoin ${ }^{1}$ and valproate bind zinc in vitro. ${ }^{2}$ The reported association between maternal valproate and phenytoin treatment and intrauterine spina bifida in both animals ${ }^{3}$ and in $\operatorname{man}^{46}$ could also be due to zinc deficiency, for zinc deprivation is teratogenic in animals, and in women is associated with intrauterine growth retardation. ${ }^{7}$ Furthermore, large doses of valproate late in pregnancy reduce fetal weight and hepatic zinc concentrations ${ }^{8}$; in rats zinc deficiency greatly increases the teratogenicity of an analogue of thalidomide. 9

Serum zinc concentrations during long term antiepileptic drug treatment may also be low, ${ }^{10-12}$ although this is disputed, ${ }^{13-16}$ but, in any event, the concentration of zinc in serum is an insensitive measure of zinc status, as it is influenced by recent dietary zinc intake, stress, serum albumin concentrations, the metabolic state of the patient, and by a circadian variation. ${ }^{17}$ In leucocytes concentrations of zinc, however, correlate with those in muscles, ${ }^{18}$ and with retinal dark adaptation, which is a functional measurement of tissue zinc status. ${ }^{19}$ Concentration of zinc in leucocytes is therefore a much better indicator of total body zinc.

Changes in the differential cell count of blood may influence the zinc concentration of mixed leucocytes as different subpopulations have different zinc contents. ${ }^{20}$ We therefore assessed zinc status from the concentrations of zinc in peripheral blood polymorphonuclear leucocytes in controls and in epileptic patients on long term antiepileptic treatment.

\section{Patients and methods}

Twenty six patients with chronic epilepsy (mean (SD) age $30(8)$ years, 15 of whom were men) were recruited from the neurological outpatient department. They did not have progressive neurological disease nor other organic illnesses. Nineteen were taking sodium valproate in addition to other antiepileptic drugs (mean (SD) 30(8) years, 12 men) and seven were taking carbamazepine alone (mean (SD) age 30(7), three men). None was taking any other drugs. In the group taking valproate, phenytoin $(n=8)$, carbamazepine $(n=7)$, phenobarbitone $(n=3)$, primidone $(n=2)$, and clonazepam $(\mathrm{n}=1)$ were also being taken.

Fourteen healthy volunteers (aged 29(7), 11 men) were recruited from the staff of St Thomas's Hospital. They were well and not taking therapeutic drugs.

Between 9 am-10 am $30 \mathrm{ml}$ of a non-fasting venous blood sample was taken and the polymorphonuclear leucocytes separated as described previously. ${ }^{18}$ The cells were lysed with dilute nitric acid, and their zinc content and that of plasma were measured by flame atomic absorption spectrophotometry (ASS) (International Laboratory model 257). Plasma concentrations of patients receiving antiepileptic drugs were also measured.

The study was approved by the ethical committee of St Thomas's Hospital, and all patients gave written informed consent.

\section{Results}

The mean (SD) zinc contents of polymorphonuclear 


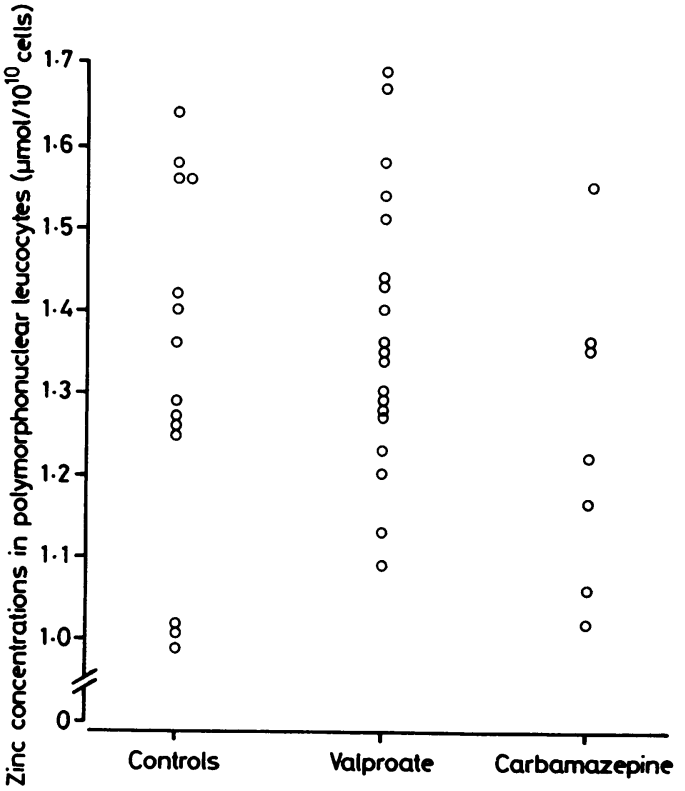

Figure Zinc concentrations in polymorphonuclear cells in patients receiving valproate or carbamazepine and in controls.

leucocytes did not differ between the groups: controls $1.33(0.22)(n=14)$; valproate $1.37(0.17)(n=19)$; carbamazepine $1.25 \quad(0.19)^{7} \quad \mu \mathrm{mol}$ zinc/ $/ 10^{10}$ cells $(\mathrm{n}=7)$ (figure).

Power calculations show that this study had an $80 \%$ chance at the $5 \%$ level of significance of detecting a difference of $0 \cdot 19 \mu \mathrm{mol} / 10^{10}$ cells $(14 \%)$ between the controls and valproate group.

Plasma zinc concentrations also did not differ between the groups: controls $14.66(1.68)(n=14)$; valproate 14.05 (1.47) $(n=19)$; carbamazepine 13.44 (1.68) $\mu \mathrm{mol} / \mathrm{l}(\mathrm{n}=7)$, but albumin concentrations were not measured.

Of the patients taking sodium valproate, the mean (SD) valproic acid concentration was $388(125) \mu \mathrm{mol} / \mathrm{l}$ (range 140-588) $(n=18)$. There was no correlation between zinc and valproic acid concentrations. The patients taking carbamazepine alone had a mean concentration of $28.3(7.4) \mu \mathrm{mol} / \mathrm{l}$ (range 16.2-38.3) $(\mathrm{n}=7)$.

\section{Discussion}

Zinc deficiency was recently suggested to be present in two patients with epilepsy, skin rashes, and low serum zinc concentrations receiving long term antiepileptic drugs $^{21}$; these rashes resolved with oral zinc treatment. Another patient taking primidone and phenytoin had recurrent trichomoniasis and also had a low serum zinc concentration; the trichomoniasis resolved with oral zinc treatment. ${ }^{22}$ It is difficult to explain these reports, although patients may have had poor zinc intakes.

This study, however, did not indicate any difference in tissue zinc status, as measured by polymorphonuclear leucocyte zinc concentrations between patients taking antiepileptic drugs and healthy controls, even though the study had an $80 \%$ chance of detecting a true difference of $14 \%$. It is therefore unlikely that total body zinc is greatly affected by antiepileptic drugs.

Plasma zinc concentrations are variously reported to be normal or reduced in patients receiving antiepileptic drugs, ${ }^{10-1623}$ although interestingly, plasma copper concentrations, which rise in zinc deficiency, ${ }^{24}$ are almost invariably raised, ${ }^{11423}$ and in one report erythrocyte zinc concentrations fell. ${ }^{25}$ In rats treatment with valproic acid reduces plasma zinc concentrations, ${ }^{16}$ but at best plasma zinc concentrations inconstantly reflect body zinc status. ${ }^{18}$

It is possible that antiepileptic drugs affect the intracellular distribution of zinc. Thus phenytoin may increase the intestinal absorption of zinc by chelation ${ }^{1}$; valproate and phenytoin bind zinc in vitro. ${ }^{16}$ Perhaps antiepileptic drugs therefore chelate zinc within cells $^{1425}$ and reduce its availability to metalloenzymes. Treatment with oral histidines has been reported to cause neurological symptoms that were rapidly reversed by zinc supplementation, ${ }^{26}$ and to increase urinary zinc loss, although this was too small to cause a clinically important reduction of body stores. The amino acid may therefore have entered the brain and redistributed the metal within cortical cells. Similarly, concentrations of zinc in leucocytes are raised in untreated cystinuria, suggesting that cystine may also chelate zinc within cells. ${ }^{27}$ It is therefore even possible that antiepileptic drugs prevent the fall of zinc in leucocytes in cases of zinc depletion.

In conclusion, our results suggest that tissue zinc depletion is not caused by antiepileptic drugs, although it remains possible that they affect the intracellular distribution of zinc.

We are grateful to Linda Carlsson for spectrophotometry, Dr Christine Knott for measuring antiepileptic drug concentrations, Professor SE Smith for helpful discussion, to the Special Trustees of St Thomas's Hospital for their continuing support, and to the neurologists for allowing us to study their patients.

\section{References}

1 Weismann K, Knudsen L, Hoyer $\mathbf{H}$. Phenytoin increases ${ }^{65}$ zinc absorption in the rat. $J$ Invest Dermatol 1978;71:396-7.

2 Hurd RW, Wilder BJ, Street JJ, Sciscent GL. Zinc binding by 
valproic acid. Neurosci Abstr 1981;7:813.

3 Hurd RW, Wilder BJ, Van Rinsvelt HA. Valproate, birth defects, and zinc. Lancet 1983;i:181.

4 Lindhout D, Schmidt D. In-utero exposure to valproate and neural tube defects. Lancet 1986;i:1392-3.

5 Robert E, Lofkvist E, Mauguiere F. Valproate and spina bifida. Lancet 1984;ii:1392.

6 Strickler SM, Dansky LV, Miller MA, Seri MH, Andermann E, Spielberg SP. Genetic predisposition to phenytoin-induced birth defects. Lancet 1985;ii:746-9.

7 Meadows NJ, Ruse W, Smith MF, et al. Zinc and small babies. Lancet 1981;ii:1135-7.

8 Vormann J, Hollriegl V, Merker HJ, Gunther T. Effect of valproate on zinc metabolism in fetal and maternal rats fed normal and zinc-deficient diets. Biol Trace Element Res 1986;10:25-35.

9 Jackson AJ, Schumacher HJ. The teratogenic activity of a thalidomide analogus EM12 in rats on a low-zinc diet. Teratology 1979;19:341-4.

10 Barbeau A, Donaldson J. Zinc, taurine, and epilepsy. Arch Neurol 1974;30:52-8.

11 Scott GD, Delves HT. Plasma zinc levels with anticonvulsant therapy. Br J Clin Pharmacol 1978;5:279-80.

12 Higashi A, Ikeda T, Matsukura M, Matsuda I. Serum zinc and vitamin $\mathrm{E}$ concentrations in handicapped children treated with anticonvulsants. Dev Pharmacol Ther 1982;5:109-13.

13 Vasiliades J, Sahawneh T. Effect of diphenylhydantoin on serum copper, zinc, and magnesium. Clin Chem 1975;21:637-8.

14 Palm R, Hallmans G. Zinc and copper metabolism in phenytoin therapy. Epilepsia 1982;23:453-61.

15 Ghose K, Taylor A. Hypercupraemia induced by antiepileptic drugs. Hum Toxicol 1983;2:519-29.

16 Hurd RW, Van Rinsvelt HA, Wilder BJ, Karas B, Maenhaut W,
De Reu L. Selenium, zinc, and copper changes with valproic acid: Possible relation to drug side effects. Neurology 1984;34:1393-5.

17 Lifshitz MD, Henkin RI. Circadian variation in copper and zinc in man. J Appl Physiol 1971;31:88-92.

18 Jones RB, Keeling PWN, Hilton PJ, Thompson RPH. The relationship between leucocyte and muscle zinc in health and disease. Clin Sci 1980;60:237-9.

19 Keeling PNW, O'Day J, Ruse W, Thompson RPH. Zinc deficiency and photoreceptor dysfunction in chronic liver disease. Clin Sci 1982;62:109-11.

20 Simmer K, Thompson RPH. Maternal zinc and intrauterine growth retardation. Clin Sci 1985;68:395-9.

21 Lewis-Jones MS, Evans S, Culshaw MA. Cutaneous manifestations of zinc deficiency during treatment with anticonvulsants. Br Med J 1985;290:603-4.

22 Wilmott F, Say J, Downey D, Hookham A. Zinc and recalcitrant trichomoniasis. Lancet 1983;i:1053.

23 Werther CA, Cloud H, Ohtake M, Tamura T. Effect of long-term administration of anticonvulsants on copper, zinc, and ceruloplasmin levels. Drug Nutrient Inter 1986;4:269-74.

24 Lerman-Sagie T, Statter M, Szabo G, Lerman P. Effect of valproic acid therapy on zinc metabolism in children with primary epilepsy. Clin Neuropharmacol 1987;10:80-6.

25 Strain WH, Hirsh FS, Michel B. Increased copper/zinc ratios in acrodermatitis enteropathica. Lancet 1974;i:1196-7.

26 Henkin RI, Patten BM, Re PK, Bronzert DA. A syndrome of acute zinc loss. Arch Neurol 1975;32:745-51.

27 Ruse W, Keeling PWN, Thompson RPH, Mansell MA. Zinc and cystinuria. Clin Sci 1982;63:223-4.

Requests for reprints to: Dr RPH Thompson, The Rayne Institute, St Thomas' Hospital, London SE1 7EH, England. 